\title{
Japanese Taxation of Stock Options: Enactment of US-type ISO Encouraged
}

\author{
Toshiaki Katsushima, Deloitte Touche Tohmatsu, Tokyo
}

Will the taxation of Japanese stock options be revised to provide maximum incentives to employees and assist in stimulating the Japanese stock market? Recent developments indicate that consideration is being given to these issues.

In the United States, the federal tax treatment of incentive stock options (hereafter referred to as 'ISOs') can provide significant economic incentives to employees. The economic incentive encourages employees to further enhance the value of their employer's stock by increased work effort, creativity, etc. The United States is currently enjoying a very bullish stock market,

Although an oversimplification, basically, a US-type ISO is structured and taxed in the United States as follows. An employee meeting specified longevity requirements is granted an ISO. The exercise price per share is generally set equal to the underlying share's fair market value on the date of grant. There is no regular US federal income tax assessed at the date of exercise. If the employee sells the underlying share(s) more than two years after the date of grant and more than one year after the date of exercise, then the gain (difference between exercise price and sales price) is classified as a capital gain. Capital gains are subject to lower federal maximum rates (currently 28 per cent; 10 per cent to 28 per cent under the new US tax reform; 8 per cent to 28 per cent in tax years beginning after 2000).

Unfortunately, under current Japanese tax law, a Japan-resident individual granted a stock option is disadvantage in comparison with his/her US associates. Under current law, generally, the individual is subject to Japanese individual income tax on the date of exercise of the option. The amount subject to tax is the excess of the fair market value of the underlying shares on the date of exercise over the exercise price. In addition, this 'spread' is now generally classified for Japanese individual income tax purposes as 'employment income'. For highly compensated individuals, employment income can be subject to a maximum Japanese effective individual income tax rate of up to 61.75 per cent.

It may be noted that under previous law, a position could arguably be taken that the spread could be classified as occasional income unless received by individuals in lieu of employment income. Japanese individual income tax law provides for preferential tax treatment of occasional income. Basically, 50 per cent of occasional income is exempt from Japanese income taxation. This reduces the maximum potential Japanese tax rate to about 32.5 per cent and correspondingly reduces the number of shares needed to be sold to pay the resulting Japanese income tax.

Unfortunately, the Japanese tax authorities revised the previously issued tax circular on the taxation of stock options. The revision indicates that stock option income should be treated as employment income under most circumstances. The circular states that this treatment is effective for options exercised on or after 1 January 1997.

Last year, Japan introduced legislation allowing the creation of special stock options which are taxed similar to US ISOs: no Japanese income at the time of exercise and any gain taxed at currently preferential Japanese capital gain rates at the time the shares are sold. However, the special options are very limited in that they are targeted towards high-tech venture capital types of newly formed companies with very strict limits as to the number of shares allowed to be purchased.

It has recently been disclosed that the Japanese Ministry of Finance is reportedly studying changing the Japanese income tax treatment of stock options. Under consideration is taxation timing similar to ISOs in the United States. This would be welcome relief, as, if enacted, there should be no charge to tax on the date of exercise. However, it is also understood that consideration is being given to eliminating the preferential capital gain tax rate (currently 26 per cent tax on the gain; elective 1 per cent gross tax for publicly traded shares).

If the timing of the taxation can be deferred to the date of sale of the shares and some form of beneficial treatment accorded to capital gain, individuals should be able to sell shares based solely on market considerations (as opposed to paying taxes at date of exercise), encourage individuals to enhance the value of their employer's shares, and provide the necessary stimulus to the relatively bearish Japanese stock market. It will be interesting to see whether the two studies can be coordinated to achieve maximum effect from making stock options generally available and retain beneficial capital gains taxation. 